\title{
Poesia de cordel no Facebook: as potencialidades do suporte no caso do cordel "Política x Amizade"1
}

\section{Cordel on Facebook: support capabilities in}

\section{the case of the string "Política x Amizade"}

Maria Gislene Carvalho Fonseca²

1 A primeira versão deste texto foi apresentada no seminário Polarizações, promovido pelo Grupo de Pesquisa Mídia e Narrativa, da Pontifícia Universidade Católica de Minas Gerais (PUC Minas), em Belo Horizonte, de 3-5 de novembro de 2015. 
Neste artigo analisamos as potencialidades que o suporte do Facebook oferece ao dispositivo da poesia de cordel a partir do vídeo "Política x Amizade", de Bráulio Bessa. Realizamos uma análise do texto do poeta sobre a disputa de ideias nas redes sociais, no contexto das eleições presidenciais de 2014, e as implicações de sua veiculação no Facebook. Nosso objetivo é relacionar o conteúdo dos versos que discutem a polarização e os embates na rede às potencialidades que o suporte oferece à poesia de cordel, o que nos leva a perceber que o dispositivo e o conteúdo estão diretamente ligados na produção de sentidos.

\section{Palavras-chave}

Cordel, redes sociais, Facebook, Bráulio Bessa. 
Abstract

This study analyzes the potential that Facebook offers to Cordel poetry from the video "Política x Amizade" by Braulio Bessa. It presents an analysis of the political ideas' debate in social networks in the context of the presidential Brazilian elections in 2014, and the implications of its dissemination on Facebook. Our goal is to relate the content of the verses that discuss the polarization and conflicts on the network to the potential that Facebook offers to Cordel poetry, which leads us to realize that the digital platform and the content are directly linked to the production of meaning.

Keywords

Cordel, social networks, Facebook, Bráulio Bessa. 
O folheto de cordel pode ser reconhecido em diferentes suportes. Sua matriz oral configura uma poesia com características específicas de rima, métrica e ritmo, que são transcritas para o folheto e digitalizadas na internet. A internet possibilita ainda outras potencialidades que retomam a performance, a partir da produção de vídeos e de seu compartilhamento em redes sociais. Utilizando esses recursos, o poeta cearense Bráulio Bessa fez um vídeo em que canta os versos "Política $x$ Amizade", falando sobre o contexto das eleições presidenciais de 2014 e sobre as discussões que se davam nas redes sociais em torno de posicionamentos distintos, chegando-se a romper amizades - pelo menos virtualmente.

Neste trabalho buscamos identificar como a poesia de cordel, no contexto dos posicionamentos políticos polarizados, tem na rede social Facebook um espaço de visibilidade e repercussão, a partir dos versos de Bessa (2014), que tratam justamente das discussões travadas online sobre a temática política. No dia 27 de outubro de 2015, a postagem do vídeo com a declamação tinha 14.701 compartilhamentos, 7.169 curtidas e 187 comentários, números que fizeram com que o vídeo de 1'10 minutos fosse escolhido para esta análise. A abordagem proposta leva em consideração a relação que se estabelece entre a disponibilização do vídeo e os significados trazidos pelos versos cantados no que se refere à produção de sentidos das polarizações.

Para isso, devemos refletir sobre as materialidades da poesia de cordel, que preparam para os sentidos e que significam a forma como os cordelistas utilizam as tecnologias de comunicação disponíveis, apropriando-se de suas potencialidades para a distribuição, comercialização e visibilidade de suas produções. Assim, associamos as características da performance poética às características da rede social Facebook, que estão aliadas à produção do conteúdo poético e interferem em seus sentidos e alcance. Dessa forma, observamos a polaridade de posicionamentos não a partir de discursos panfletários, mas de como um poeta cordelista olha para o contexto das polarizações, e o interpreta e ressignifica a partir de suas experiências discursivas.

Realizamos, para isso, uma revisão teórica e conceitual. Em seguida, nossa observação empírica analisa as características tornadas possíveis pela utilização do Facebook como suporte técnico por Bessa, de forma que possamos compreender impactos que esta materialidade pode oferecer à poesia de cordel, pensando, assim, conteúdo e dispositivo integrados, interferindo-se mutuamente. Outro procedimento metodológico para o desenvolvimento do trabalho foi uma entrevista realizada com Bessa no dia 12 de agosto de 2015 (por Skype), com duração de 47 minutos, abordando temas como a produção poética e sua inserção nas redes sociais como parte do caminho para que ele chegasse à Rede Globo. O que buscamos compreender é como a utilização do Facebook está aliada à visibilidade da poesia de cordel. 


\section{Polarizações: embates nas redes sociais}

No contexto eleitoral de 2014, mais especificamente durante o segundo turno das eleições, disputaram a presidência a candidata à reeleição Dilma Rousseff, pelo Partido dos Trabalhadores (PT), e o senador pelo estado de Minas Gerais, Aécio Neves, candidato pelo Partido da Social Democracia Brasileira (PSDB). Essa não foi a primeira vez que PT e PSDB disputaram, em segundo turno, a presidência. Isso ocorreu em 1998, 2002, 2006, 2010 e, enfim, em 2014. O que tivemos de novidade é que essas foram as primeiras eleições presidenciais pós Jornadas de Junho de 2013, movimento que apontou uma série de insatisfações populares, com grande adesão, sob o slogan "O gigante acordou". Naquele momento, associado a um acesso diversificado às mídias sociais conectadas - ambiente de produção de conteúdo compartilhado entre uma rede de amigos ou de forma pública, a depender da privacidade escolhida pelo indivíduo dono da página -, as pessoas têm um espaço em que podem manifestar suas opiniões diante dos acontecimentos e compartilhar informações (muitas vezes sem que seja verificada a validade e credibilidade do material).

Dessa forma, com uma maior diversidade de opiniões expostas, a princípio, maior seria o diálogo possível. Obviamente, não apontamos aqui que esse diálogo signifique uma mídia democrática, mas temos outros lugares de fala diversos da hegemonia de sentidos que vigorou, por exemplo, pela televisão e pelo alcance da Rede Globo em momentos anteriores. O que estamos apontando é para uma ampliação de vozes que podem ser lidas e, portanto, debatidas em seu ambiente de produção e recepção, mesmo reconhecendo que há vozes silenciadas pela ausência de visibilidade mesmo nestes espaços por uma série de limitações econômicas, técnicas e políticas, mas que não nos cabe discutir nesse momento, por não ser essa a nossa proposta. Olharemos para as vozes expostas.

Com vozes diversas e com a possibilidade de interatividade, de respostas imediatas, os debates se iniciaram. Posicionamentos distintos ofereceram a possibilidade de se construírem diálogos de modo que a diversidade de pensamentos pudesse ser explorada. Mas, em vez disso, o que percebemos foi uma polarização criada a partir de intrigas entre pessoas de posições diferentes. Fugimos de uma explicação psicológica para isso, que definiria o conflito como de natureza humana - afinal, nossa proposta não é a de explicar o conflito, mas de reconhecer sua existência que justifica o discurso poético aqui trabalhado.

O que temos, por sua vez, é uma disputa de sentidos a partir da linguagem (HALL, 2013). Segundo Hall (2010), o sentido é uma produção social, portanto os signos não têm significados intrínsecos, mas são resultados de práticas cotidianas. A linguagem é polissêmica e é seu uso cotidiano que the atribui sentidos. Por isso não podemos falar em uma linguagem estática, fixa. As palavras são 
historicamente ressignificadas justamente porque o sentido é uma prática social e decorre de empregos e interpretações que variam porque a consciência individual é socioideológica, de acordo com Bakhtin (2012):

As relações sociais evoluem (em função das infraestruturas), depois a comunicação e a interação verbais evoluem no quadro das relações sociais, as formas dos atos de fala evoluem em consequência da interação verbal, e o processo de evolução reflete-se, enfim, na mudança das formas da língua (BAKHTIN, 2012, p. 129).

A interação é uma negociação de significados posta em prática através dos enunciados. Segundo Hall (2013), trata-se de uma luta pelo domínio no discurso, que no cordel verifica-se a partir de uma luta pela legitimação da ideia de "verdade" em seu interior. Essa luta se dá pela multiplicidade de significados possíveis aos signos, atribuíveis culturalmente, pelo seu uso cotidiano. Sendo os signos polissêmicos, cada interlocutor os enuncia de forma distinta, partindo da rede de diálogos sociais da qual participa. A significação decorre das práticas sociais e a partir das relações sociais temos uma transformação nos sentidos, que evoluem historicamente por serem tais práticas dotadas de ideologias. Assim, devemos pensar a importância da cultura nesse processo de interação, pois "é dentro dos sistemas de representação da cultura e através deles que nós 'experimentamos o mundo': a experiência é o produto de nossos códigos de inteligibilidade, de nossos esquemas de interpretação" (HALL, 2013, p. 200).

Essa disputa, quando transferida da virtualidade latente para a vida cotidiana, causa justamente o que aborda Bessa (2014) nos versos discutidos mais adiante. Versos que ganharam visibilidade a partir do que o Facebook possibilita em torno dos compartilhamentos e do que Jenkins (2014) chama de propagabilidade, ou seja, "o potencial - técnico e cultural - de os públicos compartilharem conteúdos por motivos próprios, às vezes com a permissão dos detentores dos direitos autorais, às vezes contra os desejos deles" (JENKINS, 2014 , p. 26). Ainda segundo o autor, as mídias digitais seriam catalizadoras da reconceituação de fatores culturais que têm implicação nas relações sociais e, portanto, nas formas de participação política. Por isso, refletimos aqui como o Facebook, nesse contexto de polarização e conectividade, contribui para a visibilidade do cordel como lugar de produção de sentidos.

\section{O cordel e suas materialidades}

Segundo Mouillaud (1997), não há uma dicotomia entre dispositivo e sentido. Eles estão intimamente relacionados, influenciando-se mutuamente. $O$ 
sentido é predisposto pelo dispositivo que o carrega, pois "o dispositivo prepara para o sentido" (MOULLIAUD, 1997, p. 30). Dessa forma, podemos pensar na poesia do cordel combinada às diferentes materialidades como uma preparação de sentidos, ou seja, devemos partir da compreensão da linguagem do cordel pela matriz oral que a estrutura, ainda que seja apresentada em folhetos ou na internet.

Ainda segundo Mouillaud (1997), os discursos não estão soltos no espaço. Sua materialidade prepara para seu sentido, sendo fundamental considerá-la nas análises. No caso do cordel, a forma poética é uma preparação para o conteúdo, que aciona nos leitores/ouvintes um contrato de enquadramento, que define, a princípio, regras de leitura e de compreensão. Mas, constantemente, a poesia quebra com os pressupostos de leitura definidos pelas formas canônicas de poesia, principalmente quando se propõe a tratar de notícias e de fatos do cotidiano.

O Facebook é tratado aqui como suporte à poesia, que seria abstrata e impossível de ser apreendida se não tivesse forma, fosse pela voz, fosse pelo papel. Nesse caso, o Facebook como materialidade é dotado de características específicas que oferecem possibilidades aos conteúdos nele disponibilizados; por isso é importante compreendê-lo, também, como dispositivo intercruzado ao dispositivo poético.

Essa discussão levanta o que Mouillaud (1997) chama de ponto de vista genético do dispositivo, ou seja, quando o conteúdo demanda a criação e a utilização de novos suportes, de materialidades e formas diferentes de apreensão do tempo e do espaço. No cordel, isso acontece quando a circulação da poesia oral demanda a utilização de outros suportes técnicos, alterando a manifestação de um dispositivo que pressupunha, inicialmente, apenas a voz como materialidade. Com a necessidade de comercialização da poesia e a possibilidade de impressão pela chegada das máquinas tipográficas ao interior do país, e com o uso das xilogravuras, os versos passam a circular na forma de folhetos. Também por critérios comerciais, o cordel chega à internet como forma de divulgação, mas também para que, ao tratar de conteúdos efêmeros, os cordelistas não tenham prejuízos com folhetos impressos e que deixam de ser vendidos quando a novidade passa e os folhetos perdem a atualidade.

No caso da poesia oral, há características, como métrica e rima, que são adequadas ao ritmo ao qual se propõe. Ela, por ser declamada, precisa ser agradável aos ouvidos de seu público. O autor cria uma espécie de diálogo com seus receptores, permitido pela flexibilidade que a voz possui. Essa forma, que é escrita e impressa nos folhetos, também é definidora do que encontramos na internet e permanecemos chamando de cordel. O conteúdo da poesia oral faz parte da memória coletiva, das tradições, transmite mensagens, comunica, informa, opina. 
Mostra a subjetividade do poeta dentro de sua cultura, inserido socialmente em uma comunidade, poetizando e compartilhando os elementos culturais que a compõem.

Sabe-se que embora impresso e veiculado pelo folheto, o cordel é uma forma de literatura oral feita expressamente para ser recitada. A rima do cordel é feita para o ouvido e a memória, não para os olhos. Ela é antes de tudo mnemônica e comunicativa. O folheto é apenas o suporte material de uma poesia que permanece oral (KUNZ, 2001, p. 79-80).

Reconhecemos que as materialidades da poesia na voz, no papel e na internet oferecem, como afirma Santos (2010), processos comunicativos diferentes, que pressupõem temporalidades diversas de produção e de consumo. "Na internet, embora o desafio se realize na escrita, a dicção poética é a dos textos orais, o que é uma característica indiscutível em toda a produção de poesia tradicional nordestina, feita na hora, ou não" (AMORIM, 2008, p. 106). Desse modo, há algo que, mesmo utilizando suportes diversos, permanece e caracteriza essa poesia como cordel. Esse algo reside na linguagem. São seus elementos estruturais definidores: a métrica, o ritmo, a rima. É claro que cada suporte oferece diferentes potencialidades ao conteúdo, por isso olhamos para o cordel no Facebook. É a poesia de matriz oral e sua linguagem que definem o que chamamos de poesia de cordel.

Considerar o uso das tecnologias e a evolução de seu suporte material, segundo Lemaire (2010, p. 75), é fundamental para compreendermos a poesia de cordel como um fenômeno vivo e em permanente movimento. E a evolução do cordel poderia ser descrita como um capítulo da história das tecnologias da informação e da comunicação.

Eles permitiram demonstrar que houve, na verdade, um aproveitamento inteligente, bem organizado e eficaz da nova tecnologia. Não foi uma simples utilização/adaptação, mas uma apropriação e reinvenção, adaptadas às condições de vida dos poetas individuais; houve a elaboração de autênticos sistemas editoriais alternativos; quer dizer: a própria produção material dos folhetos tem a sua história que já comporta vários capítulos, indo da pequena máquina artesanal, instalada na casa do poeta para uso pessoal, passando por pequenas empresas artesanais já bem organizadas e chegando a editoras com catálogo, redes de publicidade, de divulgação e distribuição (LEMAIRE, 2010, p. 77). 
É o que percebemos também com a utilização da internet como espaço de divulgação e circulação da poesia de cordel. Há uma resistência por parte dos poetas mais conservadores que afirmam que, ao utilizar o espaço virtual, a poesia deixa de ser cordel. Mas há também poetas que utilizam a internet e as redes sociais para divulgar sua poesia e que a tomam como aliada do processo criativo o que, inclusive, facilita outras formas de performance, de modo a manter a matriz oral dos versos e sua circulação, por exemplo, por vídeos e áudios.

A utilização de novas tecnologias não necessariamente exclui as formas anteriores, mas podem combinar-se e coexistir. Foi assim no folheto, que, segundo Santos (2010, p. 50), mesmo impresso permanece sendo utilizado para cantorias e declamações pelos poetas ou pelos leitores, que podem carregá-los. É assim na internet, em que as performances podem ser compartilhadas, mesmo que os contextos de consumo sejam diferentes em cada enunciação.

O poeta, mesmo se apropriando dessa evolução, não perde de vista elementos fundamentais que caracterizam a poesia de cordel, a exemplo de sua matriz oral, que está na base de sua existência, bem como sua dimensão tradicional, no que tange ao imaginário popular e à própria função que desempenha o poeta junto aos seus leitores (MENDES, 2010, p. 143).

Desse modo, num sentido de utilização de mais uma tecnologia disponível, poetas cordelistas passam a utilizar perfis no Facebook para divulgar seus trabalhos poéticos. O Facebook é uma rede social que possui cerca de 1,44 bilhão de usuários ao redor do mundo, segundo o balanço divulgado pela própria empresa em abril de 2015. Nessa rede, as pessoas podem fazer postagem de textos, de imagens, de vídeos, de enquetes, curtir, reagir, comentar e compartilhar oa conteúdos, participar de grupos, enviar mensagens instantâneas, ter a conta vinculada a outras redes como Instagram, Twitter e Whatsapp etc. Do Facebook emergem possibilidades que modificam as relações entre produtores e consumidores de conteúdos. As fronteiras que demarcariam tais limites se perdem.

A mídia social conectada é um formato de comunicação mediada por computador (CMC) que permite a criação, o compartilhamento, comentário, avaliação, classificação, recomendação e disseminação de conteúdos digitais de relevância social de forma descentralizada, colaborativa e autônoma tecnologicamente. Possui como principal característica a participação ativa (síncrona e/ou assíncrona) da comunidade de usuários na integração de informações (LIMA JR., 2009, p. 97). 
Nesse ambiente estão também os poetas cordelistas. Aqui, há uma relação em que a audiência é muito mais participativa do que em outros veículos. Os poetas, que já tinham seu próprio canal - os folhetos - estão em um novo ambiente, vivendo e usufruindo um contexto de convergência midiática.

Mais do que apenas estarem na internet como suporte ou depositório de conteúdos, a utilização das redes sociais, especificamente do Facebook, significa um trajeto em busca de visibilidade possibilitada pelas potencialidades características da rede, a saber, a multimidialidade, que permite que a poesia da voz seja explorada não somente em texto, mas também em performance por meio de vídeos e áudios; a possibilidade de compartilhamento em rede desse material, o que significa um alcance mais amplo pois cada perfil que compartilha os conteúdos se torna um veículo de divulgação que se multiplica exponencialmente; os comentários, que podem servir tanto como resposta como para a elaboração de uma peleja virtual; as curtidas, reações, que funcionam como termômetro de interesses temáticos aos poetas.

São essas potencialidades que nos interessam neste artigo. Como características de um suporte específico, interferem na forma e no conteúdo dos versos de cordel. Iremos observar como essas mesmas potencialidades são utilizadas e repercutem no processo produtivo de cordelistas e, ainda, o que se modifica e o que se mantém na poesia. Finalmente, obsevaremos como a poesia, no caso de Bessa (2014), está atravessada pelo contexto político de quando foi produzido e pelo suporte material que o abriga.

\section{As potencialidades da internet como aliadas da poesia de cordel}

No contexto de polarização de posicionamentos manifestos nas redes sociais, muitos poetas cordelistas divulgam as próprias opiniões no Facebook, seja em versos, seja comentando alguma notícia ou boato recorrente em contexto de eleições, ou mesmo compartilhando imagens e memes ${ }^{3}$ disponíveis nas diversas páginas. Identificamos em uma leitura assistemática ${ }^{4}$, sem critérios definidos de observação - apenas acompanhando poetas que fazem parte de páginas e grupos de cordelistas que acompanho e dos quais faço parte - poetas que manifestaram apoio ao candidato Aécio Neves e às ideias associadas à sua campanha; e outros

\footnotetext{
3 Termo utilizado segundo a definição de Granja (2012, p. 41): "Hoje em dia se usa o termo para todas as coisas que são utilizadas repetidamente na internet em vários contextos e formatos diferentes".

4 Nesse momento, refiro-me ao meu próprio perfil de Facebook e, por isso, não o incluí como procedimento metodológico, visto que há uma subjetividade manifesta no que se refere aos conteúdos de poetas que conheço pessoalmente ou recomendados por outras pesquisadoras e outros pesquisadores, com quem já tive alguma troca de informações e conteúdos. Não seria possível, assim, realizar um distanciamento do corpus de análise e falar em métodos como pesquisa exploratória, observação participante ou netnografia. Por isso, assumo a primeira pessoa do singular para referir-me ao lugar de observação, voltando em seguida ao plural do discurso acadêmico.
} 
que apoiavam a reeleição da candidata Dilma Rousseff e as ideias associadas à sua campanha; e poetas que não apoiavam nenhum dos candidatos, defendendo uma reforma política que negasse a dualidade PT $x$ PSDB e ideias vinculadas a revindicações de movimentos sociais.

Além dessas manifestações, identificamos também o vídeo publicado por Bessa (2014), que nos despertou interesse no que se refere ao conteúdo, ou seja, a narrativa, a princípio anônima, sobre uma situação que vinha acontecendo no Facebook no contexto das eleições e ao formato de performance possibilitado pela utilização de vídeo na internet, combinada às outras linguagens utilizadas por outros poetas. Os versos são os seguintes:

Pra você que defende um candidato Joga murro, esculhamba e dá bofete Arengando e brigando na Internet Eu não quero cortar o seu barato Mas Ihe peço que seja mais sensato Amizade é um bem que não se mede Dá é pena de um amigo que perde Se intrigando nesse tempo de eleição Ter respeito é nossa obrigação Cada um sabe o que cheira e o que fede

Pois enquanto tem gente aqui brigando Candidato nenhum quer nem saber (homi) O pau quebra no debate da TV No final já tão tudo se cheirando E você sendo besta, se lascando Os amigos se afastando de você A política Ihe cegando pra não ver Com amigo de verdade não se implica Pois enquanto você briga por política Os políticos tão brigando por você? (BESSA, 2014).

As formas em que a poesia de cordel se apresenta no Facebook são comumente a publicação do texto escrito acompanhado de alguma imagem que o ilustre. Pode ser alguma imagem pública da internet sobre o tema trabalhado, uma xilogravura ou mesmo a capa do folheto que se pretende divulgar. Outra forma é o compartilhamento de links externos ao Facebook, que direcionam o leitor a blogs dos poetas, nos quais ficam disponíveis poesias, áudios e vídeos. Há ainda poetas que compartilham seus versos no formato imagético, combinando texto e imagem (sua própria foto ou algum tipo de ilustração), e os textos que são transformados 
em imagem com logotipo que remete à xilogravura e à estética do cordel. Há a possibilidade de encontrarmos, ainda, pelejas realizadas em grupos ou mesmo nas páginas pessoais, utilizando-se o recurso dos comentários.

Todos estes formatos, de algum modo, utilizam as já mencionadas potencialidades do Facebook. Seja como mensuração de aprovação pelas curtidas, seja pela visibilidade possibilitada pelos compartilhamentos, seja pela apreciação ou pela criação coletiva realizada nos comentários. A especificidade da poesia de Bessa (2014) é que ela não aparece escrita, mas em vídeo, no qual o poeta declama os versos, destacando assim uma característica fundamental da poesia oral, que é a performance.

No caso específico dos versos "Política x Amizade", o conteúdo diz respeito a uma situação que envolve as polarizações manifestas nas redes, no contexto das eleições de 2014, não apresentando algum tipo de posicionamento do poeta, mas fazendo uma crítica ao que ele percebia nas redes sociais. A poesia de cordel é um dos lugares de produção de sentidos sobre a realidade sociocultural e, neste caso das eleições, não ficou ausente da avaliação. A referência feita a um discurso de ódio ocorre na menção das situações de agressão - físicas e virtuais - presentes nos versos: "Joga murro, esculhamba e dá bofete / Arengando e brigando na Internet". O poeta, nesse momento, realiza uma apreciação sobre as polarizações, considerando que pessoas de lados opostos é que se agridem por motivações políticas. "Esculhamba" faz referência a uma agressão linguística, verbal. Estaria, ainda, no espaço latente do ambiente virtual. Mas quando, na sequência, "dá bofete", a agressão é física, externa ao ambiente virtual.

Nesse contexto, temos evidenciada a polarização pela localização de indivíduos em posições diferentes, que seriam os personagens da poesia narrada por Bessa (2014). Reiteramos que, nesse momento, o poeta não assume o seu posicionamento político, mas aponta para uma crítica à agressividade decorrente dessas polarizações, sejam elas verbais ou físicas.

Esta linha tênue entre a latência da virtualidade e a agressão real, que resulta em rompimentos de relações cotidianas, nos conduz à relação da linguagem com a construção social da realidade, compreendendo que ambas são parte de um mesmo sistema cognitivo e que faz com que os posicionamentos no campo do real sejam apresentados na rede e que, por sua vez, retornam ao real como embates políticos. Esses embates e sua consequente visibilidade decorrem, em grande parte, das potencialidades oferecidas pelo Facebook. Está sendo, assim, realizada uma associação às eleições, porque o apoio e a defesa de candidatos é mencionada como causa para essas situações. A partir daí, inicia-se um processo de aconselhamento pela valorização de amizades já existentes, visto que havia 
uma relação, ainda que virtual, pelas redes sociais, e que estavam sendo abaladas pela movimentação dos conflitos realizados devido às eleições: "Amizade é um bem que não se mede".

Segundo o poeta, não a vale a pena envolver-se nos conflitos motivados pelas eleições, o que se justifica pela indiferença que os candidatos têm com os eleitores, para quem o resultado das eleições não deveria ter influência direta a ponto de um posicionamento repercutir no rompimento de uma amizade. Os próprios candidatos, que estariam em disputa, manteriam uma relação estreita entre si, então não caberia aos eleitores repercutir o posicionamento político em forma de um "discurso de ódio": "Candidato nenhum quer nem saber (homi) / O pau quebra no debate da TV / No final já tão tudo se cheirando".

O autor fala ainda sobre a necessidade de respeito às opiniões, outro aspecto que no contexto de "discurso de ódio" é levantado. Afinal, para trabalhar os efeitos desses discursos manifestos nas redes sociais o caminho seria o respeito e a tolerância: "Ter respeito é nossa obrigação / Cada um sabe o que cheira e o que fede". Por fim, a lição que é sintetizada como moral da historia - mesmo não se tratando de uma fábula, há um sentido de aconselhamento que é proposto pelos versos - é feita a partir de um questionamento: "Pois enquanto você briga por política / Os políticos tão brigando por você?".

Assim, a proposta do poeta é criticar os movimentos de conflito levantados nas redes sociais e, ao fazê-lo, produz um conteúdo para circular por esse mesmo ambiente onde os conflitos se dão. Mas o objetivo deste artigo não é o de analisar o discurso do poeta, mas relacionar os sentidos apresentados às possibilidades que são construídas a partir da veiculação desses versos na internet.

A escolha dos versos trabalhados não aponta para uma profundidade da análise feita por Bessa em relação aos discursos de ódio, mas, em vez disso, permite-nos ver que o suporte Facebook aliado ao conteúdo poético repercute na significação e na visibilidade desses versos, fazendo com que, pela repercussão e número de compartilhamentos, o vídeo adquira representatividade no contexto político e social do momento em que foi produzido. Para Bessa, a poesia de cordel é feita para ser declamada. Dessa forma, entende que o vídeo é um canal que possibilita que os elementos da cantoria sejam mantidos, assim como outras formas de linguagem corporal - movimentos do corpo, expressões faciais - associadas à mensagem transmitida. Podemos compreender, assim, que a poesia de cordel é também multimidiática, e esta característica pode ser mantida no suporte Facebook.

Compreendendo que a multimidialidade é a produção de conteúdos em linguagens diferentes integradas, por complementaridade, para a comunicação de 
uma mensagem, temos que a poesia de cordel é multimidiática, porque integra a voz poética, o corpo (no caso de Bessa, percebido pelas expressões faciais) e o texto escrito.

A possibilidade de alcance não nos permite afirmar que a mesma poesia é "transmitida" quando compartilhada pelos usuários do Facebook seguidores de Bessa, ou seguidores de seguidores. Há um registro audiovisual da performance, mas o processo textual comunicativo é alterado a cada compartilhamento. Existe uma relação de descontextualização e recontextualização e o próprio registro é diferente de uma performance ao vivo, em que existe tanto a aura da presença do poeta como as possibilidades de modificação, impossibilitadas no registro que fixa a performance.

Assim, mesmo sabendo que o vídeo é um recurso considerado para manter a multimidialidade performática da poesia oral de cordel, não podemos pensar nele como a solução para manter as características essenciais da poesia. Porque ele é um recorte da performance que considera apenas uma situação de declamação, com estrutura montada para aquele registro. Normalmente o poeta não vê o público e a interação com ele - no caso do Facebook - é limitada ao espaço dos comentários. De todo modo, o vídeo ainda apresenta características que preparam um sentido diferente entre aquilo que é apresentado ao vivo, oralmente, e o que é escrito. Por isso a importância de pensarmos o suporte em consonância com o conteúdo.

Cada indivíduo realiza uma interpretação distinta a partir de sua experiência. E se pensarmos no mesmo indivíduo, cada novo compartilhamento e nova visualização altera o próprio vídeo, cujo conteúdo é composto também pelo status que adquire com o número de vezes em que foi executado. Um vídeo recém postado, com 200 visualizações tem uma conotação diferente de outro que registra 5 milhões, por exemplo, e que se tornou um "viral"5. Cada contexto de recepção do vídeo propõe uma significação diferente, fazendo assim com que não seja possível repetir de forma idêntica o processo comunicativo.

O número de compartilhamentos, então, está carregado de significados. Ao compartilhar algum conteúdo, o usuário poderá também complementar a significação escrevendo algum comentário com o qual irá dialogar, o que quer dizer que nem todo compartilhamento significa identificação ou concordância. É o que acontece com o vídeo "Política x Amizade". No caso da performance ao vivo, a mensuração pode acontecer pela quantidade de pessoas presentes na apresentação. No caso do Facebook, isso acontece pelo número de compartilhamentos. Assim como em uma apresentação ao vivo que esteja lotada pode significar que muitas

5 Assim como os memes, o viral se refere a um conteúdo amplamente compartilhado e acessado, que se alastra "como um vírus" e normalmente dá origem a memes. 
pessoas estão interessadas e, portanto, associa-se à qualidade de conteúdo, nas redes sociais um vídeo que virou viral pode fazer referência a um conteúdo que importa para muitas pessoas, despertando assim o interesse de mais gente que não quer ficar de fora do contexto de recepção.

Esta potencialidade relacionada à mensuração puxa imediatamente pela referência à visibilidade do vídeo. Não podemos fechar essa visibilidade somente pelo uso do Facebook, visto que uma série de elementos se combinam para que isso aconteça. Mas é particularmente sobre a parte que cabe ao uso desta rede que nos interessamos aqui. Outros ambientes como o YouTube e o Whatsapp deram suporte à circulação do vídeo de Bessa (2014) e ampliaram sua audiência, que diz do alcance atingido pelo poema.

O contexto político de controvérsias travadas nos perfis e páginas do Facebook é um elemento importante, que repercute nos discursos de ódio, porque ele desperta o interesse por uma síntese, uma explicação ou uma crítica em torno dos acontecimentos. Havendo conflitos tão constantemente na rede social, um conteúdo que sintetiza esses conflitos e os critica ganha espaço e reconhecimento. Essa visibilidade tem a ver primeiro com o conteúdo trabalhado nos versos, conforme a breve descrição realizada anteriormente. Pelo fato do poema refletir sobre uma situação sociopolítica do momento, as pessoas tiveram interesse em assumi-lo e repercuti-lo. Compartilhar, nesse momento, quer dizer "eu concordo com isso". Quanto mais indivíduos dizem concordar, pelos compartilhamentos, mais pessoas irão ver e se posicionar, aumentando a visibilidade dos versos.

Os sentidos apresentados poderiam ser atribuídos a qualquer situação de disputa eleitoral. Mas o que os situam em 2014, além da data de publicação, é a forma como a audiência se apropria deste discurso, tomando para si a crítica a um comportamento agressivo por parte dos eleitores. Essa apropriação pode ser identificada justamente pelo Facebook no contexto dos comentários, curtidas e compartilhamentos. Os números e comentários, que ficam disponíveis na página, dizem ao público se o vídeo está sendo bem recebido, se muitas ou poucas pessoas estão vendo e repercutindo, e estão diretamente associados ao conteúdo. Não temos a intenção de dizer aqui o que vem primeiro, ou definirmos o que é causa e o que é consequência no processo comunicativo, se o conteúdo ou o suporte, mas compreendermos que eles estão intimamente ligados e influenciando-se mutuamente.

No caso específico de Bráulio Bessa, a postagem trabalhada não fez referência à campanha de nenhum candidato, tampouco a propostas de reforma política em torno de uma insatisfação que alcançava a ambos os candidatos. Mas os versos fazem, no Facebook, uma análise de comportamentos assumidos no próprio 
Facebook. Desse modo, consideramos que a poesia de Bessa é metadiscursiva, pois, inserida no contexto dos discursos de ódio nas redes sociais, utiliza uma destas redes para comentar a situação que o envolve.

Trata-se, assim, de uma postagem falando sobre postagens. Um conteúdo que se volta para refletir o que se produz no dispositivo que o envolve. Conteúdo este que, por características do dispositivo, está aberto para comentários, ou seja, um elemento básico de interatividade em que o público responde de forma imediata ao texto configurado na página. Comentários, por sua vez, que são parte integrante do conteúdo. O vídeo, por si só, é apenas um dos elementos constitutivos da mensagem no Facebook. Ele se completa pela apreciação de um público que, no caso é também produtor de conteúdos, se manifesta ao compartilhar, mas também ao emitir opiniões sobre o material visualizado. Trata-se de uma atividade de diálogo que produz uma espiral de novas significações ao manter-se aberta para novas leituras e novos comentários.

O alcance dessa visibilidade, que de alguma forma comprova o papel das potencialidades do Facebook para este fim, é a chegada do poeta à mídia hegemônica. Ele sai de uma página pessoal, onde a princípio é um anônimo ("O neto de Seu Dedé Sapateiro", como traz sua descrição no Facebook, no Twitter e no Instagram) e chega a ser comentarista do programa Encontro com Fátima Bernardes, na Rede Globo, onde geralmente faz comentários em forma de poesia que seguem a métrica e o ritmo de cordel. Tal alcance decorre de uma rede de comentários e compartilhamentos de um conteúdo que se propõe multimidiático por abrir a utilização de linguagens distintas em uma mesma mensagem. O fluxo demonstra uma modificação no sentido do agendamento midiático, possibilitando que, a partir das redes sociais e das produções cotidianas de conteúdo, as pessoas que, a princípio, estariam de fora dos modos de produção passam a fazer parte, de alguma forma, do dispositivo midiático.

\section{Considerações finais}

As potencialidades do Facebook identificadas como aliadas à visibilidade da poesia de Bráulio Bessa, a saber, multimidialidade, alcance, compartilhamentos, curtidas, comentários, mensuração de visualizações são formas de produção de significado e redimensionam o modo de se fazer poesia de cordel na contemporaneidade. O público conectado, assim como aquele que acompanha presencialmente as cantorias, é também produtor desse conteúdo, que não se encerra no vídeo editado, mas está composto justamente por essa combinação entre o que o poeta produz e as repercussões junto ao público que, considerando o Facebook, constitui-se enquanto tal a partir de uma lógica informacional (emissor- 
mensagem-receptor), mas que, ao considerarmos o dispositivo em sua totalidade, tem na rede também um perfil enquanto produtor.

Mais especificamente, quando olhamos para a postagem analisada temos que o público produz sentidos que integram a totalidade significativa do vídeo. $\mathrm{A}$ poesia de Bessa arquivada em seu computador teria outra significação; circulando apenas pelo Whatsapp de pessoas conhecidas, outro tipo de sentidos seriam acionados. Mas quando inclui a participação de pessoas que repercutem o vídeo ao compartilhar, que dizem de sua importância, relevância e interesse ao curtirem, que comentam afirmando que o poeta "acerta" em seu gesto interpretativo daquele contexto, temos então uma série de significações possíveis a partir da articulação entre dispositivo e conteúdo.

O vídeo se refere às polarizações e às disputas de sentido que saem do ambiente da linguagem virtualizada e alcançam a realidade cotidiana. É assim que a linguagem atua na construção da realidade: sendo parte dela. O vídeo, como comentário, resulta justamente das polarizações e de suas consequências que transitam entre a conexão e o que está off-line. Por isso, por haver um reconhecimento de referencialidade em torno do que fala o poeta, há uma adesão e consequente propagabilidade do vídeo, que leva o poeta aos espaços da mídia hegemônica. O que o vídeo trata é da polarização, que sai da latência das redes sociais e chega ao cotidiano das pessoas que rompem relações a partir de diálogos/embates políticos.

Nossa proposta de pensar as potencialidades do dispositivo Facebook aliadas à poesia de Bessa pode também ser mobilizada para outras manifestações do cordel na internet, na medida em que essa discussão abre outros questionamentos, principalmente sobre os movimentos interpretativos da produção de significados, seja por análises de discurso, seja por análises da narrativa. Fundamental ainda seria um trabalho que contemplasse o público a partir de uma análise mais detida de comentários e compartilhamentos, que contribuiria para a compreensão desse hibridismo e para a comprovação de que a tradição não é algo estático e engessado, mas um processo de historicidade em permanente atualização.

O ponto que alcançamos nos diz de uma relação íntima e de influência mútua entre conteúdo e suporte no caso da poesia de cordel na internet. As temáticas e as formas de abordagem dos assuntos escolhidos para serem trabalhados nos versos respondem a um contexto sociocultural que emerge, inclusive, das elaborações dos poetas. O cordel está nesse lugar, sendo uma das textualidades possíveis, cujo sentido só poderá ser tomado a partir da combinação de elementos diversos que o compõem, do conteúdo ao suporte, mas principalmente das relações que os indivíduos assumem no processo. O Facebook tem colaborado para uma 
visibilidade e reconhecimento do cordel nesse lugar de produção de sentidos sobre a realidade sociocultural, contribuindo, inclusive, para o reconhecimento da legitimidade do discurso.

A internet influencia no conteúdo e nos sentidos que emergem desse conteúdo. Mas o conteúdo também influencia nos usos do próprio suporte, gerando compartilhamentos e curtidas. Trata-se, portanto, de um ciclo em que não somos capazes de identificar nem um ponto de partida, nem de chegada, mas podemos reconhecer a emergência de sentidos e de relações ao compreender que a textualidade não está fechada em um lugar específico, mas é resultado de um processo complexo, incompleto e insuficiente para entendermos as formas humanas de produzir textos sobre a vida cotidiana. 


\section{Referências}

AMORIM, M. A. No visgo do improviso ou a peleja cultural entre cibercultura e tradição: comunicação e mídia digital nas poéticas da oralidade. São Paulo: Educ, 2008.

BAKHTIN, M. Estética da criação verbal. São Paulo: Martins Fontes, 2011.

BAKHTIN, M. Marxismo e filosofia da linguagem. São Paulo: Hucitec, 2012.

BAUMANN, R; BRIGGS, C. "Poética e performance como perspectivas críticas sobre a linguagem e a vida social". Ilha Revista de Antropologia, v. 8, n. 1, 2, 2006, p. 185-229.

BESSA, B. Política x Amizade. 2014. Disponível em: https://www.facebook.com/ brauliobessauchoa/videos/720375828039081/?fref=nf Acesso: 27 out. 2015.

HALL, S. Da diáspora: identidades e mediações culturais. Belo Horizonte: Editora da UFMG, 2013.

JENKINS, Henry. Cultura da conexão: criando valor e significado por meio da mídia propagável. São Paulo: Aleph, 2014.

KUNZ, M. Cordel: a voz do verso. Fortaleza: Museu do Ceará, Secretaria da Cultura e Desporto do Estado do Ceará, 2001.

LEMAIRE, R. "Pensar o suporte: resgatar o patrimônio". In: MENDES, S. Cordel nas Gerais: oralidade, mídia e produção de sentido. Fortaleza: Expressão Gráfica, 2010.

LIMA JUNIOR, W. Mídia social conectada: produção colaborativa de informação de relevância social em ambiente tecnológico digital. Líbero, v. XII, 2009, p. 95-106.

MENDES, S. "A evolução dos suportes na literatura de cordel: um estudo do cordel panfletário". In: MENDES, S. Cordel nas Gerais: oralidade, mídia e produção de sentido. Fortaleza: Expressão Gráfica, 2010.

MOUILLAUD, M. "Da forma ao sentido". In: MOUILLAUD, M.; PORTO, S. D. (Orgs.). O jornal: da forma ao sentido. Brasília: Paralelo 15, 1997.

SANTOS, F. "Poética das vozes e da memória". In: MENDES, S. Cordel nas Gerais: oralidade, mídia e produção de sentido. Fortaleza: Expressão Gráfica, 2010. 
ZUMTHOR, P. Introdução à poesia oral. Belo Horizonte: Editora da UFMG, 2010.

submetido em: 13 mar. 2016 | aprovado em: 27 mai. 2016 